University of Nebraska - Lincoln

DigitalCommons@University of Nebraska - Lincoln

$1-1989$

\title{
Geochemical Evidence for Suppression of Pelagic Marine Productivity at the Cretaceous/Tertiary Boundary
}

James C. Zachos

University of Rhode Island

Michael A. Arthur

University of Rhode Island

Walter E. Dean

U.S. Geological Survey, Denver, CO, dean@usgs.gov

Follow this and additional works at: https://digitalcommons.unl.edu/usgsstaffpub

Part of the Earth Sciences Commons

Zachos, James C.; Arthur, Michael A.; and Dean, Walter E., "Geochemical Evidence for Suppression of Pelagic Marine Productivity at the Cretaceous/Tertiary Boundary" (1989). USGS Staff -- Published Research. 325.

https://digitalcommons.unl.edu/usgsstaffpub/325

This Article is brought to you for free and open access by the US Geological Survey at DigitalCommons@University of Nebraska - Lincoln. It has been accepted for inclusion in USGS Staff -- Published Research by an authorized administrator of DigitalCommons@University of Nebraska - Lincoln. 


\section{Geochemical evidence for suppression of pelagic marine productivity at the Cretaceous/Tertiary boundary}

\author{
James C. Zachos*, Michael A. Arthur* \\ \& Walter E. Dean $\dagger$ \\ * Graduate School of Oceanography, University of Rhode Island, \\ Narragansett, Rhode Island 02882, USA \\ $\dagger$ US Geological Survey, PO Box 25046, Denver, Colorado 80225, \\ USA
}

The normal, biologically productive ocean is characterized by a gradient of the ${ }^{13} \mathrm{C} /{ }^{12} \mathrm{C}$ ratio from surface to deep waters. Here we present stable isotope data from planktonic and benthic microfossils across the Cretaceous/Tertiary boundary in the North pacific, which reveal a rapid and complete breakdown in this biologically mediated gradient. The fluxes of barium (a proxy for organic carbon) and $\mathrm{CaCO}_{3}$ also decrease significantly at the time of the major marine plankton extinctions. The implied substantial reduction in oceanic primary productivity persisted for $\sim 0.5 \mathrm{Myr}$ before the carbon isotope gradient was gradually re-established. In addition, the stable isotope and preservational data indicate that environmental change, including cooling, began at least $200 \mathrm{kyr}$ before the Cretaceous/Tertiary boundary, and a peak warming of $\sim 3^{\circ} \mathrm{C}$ occurred $600 \mathrm{kyr}$ after the boundary event.

The section at DSDP Site 577 on the Shatsky Rise $\left(32^{\circ} 26^{\prime} \mathrm{N}\right.$, $157^{\circ} 43^{\prime}$ E) was collected by hydraulic piston core and yielded the first continuous, undisturbed sequence of pure nannofossil ooze $\left(>90 \% \quad \mathrm{CaCO}_{3}\right)$ across the Cretaceous/Tertiary $(\mathrm{K} / \mathrm{T})$ boundary. Because of the relatively shallow burial depth of the $\mathrm{K} / \mathrm{T}$ boundary sequence $(<110 \mathrm{~m}$ below the sea floor (m.b.s.f. $)^{1}$ ), the calcareous microfossils from Site 577 have not undergone significant recrystallization related to burial ${ }^{2-4}$. The position of the $\mathrm{K} / \mathrm{T}$ boundary is placed at the last appearance of planktonic foraminifera of the Abathomphalus mayaroensis zone $^{4}$ and first appearance of calcareous nannofossils of the Marcalius inversus zon ${ }^{2}$, which also coincides with peak abun- dance of magnetite-glauconite spherules at 109.09 m.b.s.f. (refs 4,5 ). A peak irridium anomaly of $61 \mathrm{ng} \mathrm{cm}^{-2}$ also occurs at the boundary, as defined by nannofossils, in adjacent Hole $577 \mathrm{~B}$ (ref. 6). The palaeodepth of Site 577 is estimated as having been $2,400 \mathrm{~m}$ at the time of the $\mathrm{K} / \mathrm{T}$ boundary ${ }^{3}$. The record at DSDP Site 577 is adequate to resolve the nature of environmental changes in pelagic settings that occurred in conjunction with the $\mathrm{K} / \mathrm{T}$ boundary event, and provides important constraints on hypotheses for extinction.

To reconstruct changes in the surface-to-deep-water carbon isotope gradient of total dissolved carbon (TDC), stable-isotope analyses were conducted on fine fraction $(<63-\mu \mathrm{m})$ carbonate and several species of planktonic and benthic foraminifera in closely spaced samples over a $10-\mathrm{m}$ interval spanning the $\mathrm{K} / \mathrm{T}$ boundary, ${ }^{3,4,7}$ (Fig. 1). The $\delta^{13} \mathrm{C}$ of fine-fraction carbonate (primarily calcareous nannoplankton) and of planktonic foraminifera from this site decreases by about $1.5 \%$ at the $\mathrm{K} / \mathrm{T}$ boundary relative to values just below the boundary. The $\delta^{13} \mathrm{C}$ values of biserial benthic foraminifera Aragonia and of trochospiral benthic foraminifera Nuttallides, Gavelinella and Gyroidinoides show an enrichment across the boundary converging with $\delta^{13} \mathrm{C}$ values of both planktonic foraminifera and finefraction carbonate just above the boundary (Fig. 2).

Convergence of $\delta{ }^{13} \mathrm{C}$ values of planktonic foraminifera, nannoplankton (fine-fraction) and benthic foraminifera indicates that the biologically mediated gradient in carbon isotopes between the surface and deep waters, which is characteristic of productive oceans, effectively disappeared at the K/T boundary. Such conditions have been termed a 'Strangelove' ocean on the basis of predictions for events following a mass extinction ${ }^{8,9}$. The loss of a surface-to-deep-water carbon isotope gradient could only be caused by a major reduction in primary production or by extremely rapid rates of oceanic turnover. At Site 577 the lack of a carbon isotope gradient suggests that a poorly productive ocean persisted for at least $0.5 \times 10^{6} \mathrm{yr}$ following the $\mathrm{K} / \mathrm{T}$ boundary event (Fig. 2). The gradual development of a surfaceto-deep-water $\delta^{13} \mathrm{C}$ gradient in the period following this interval probably represents a progressive increase in primary production.

The changing offset of $\delta^{13} \mathrm{C}$ between biserial and trochospiral 


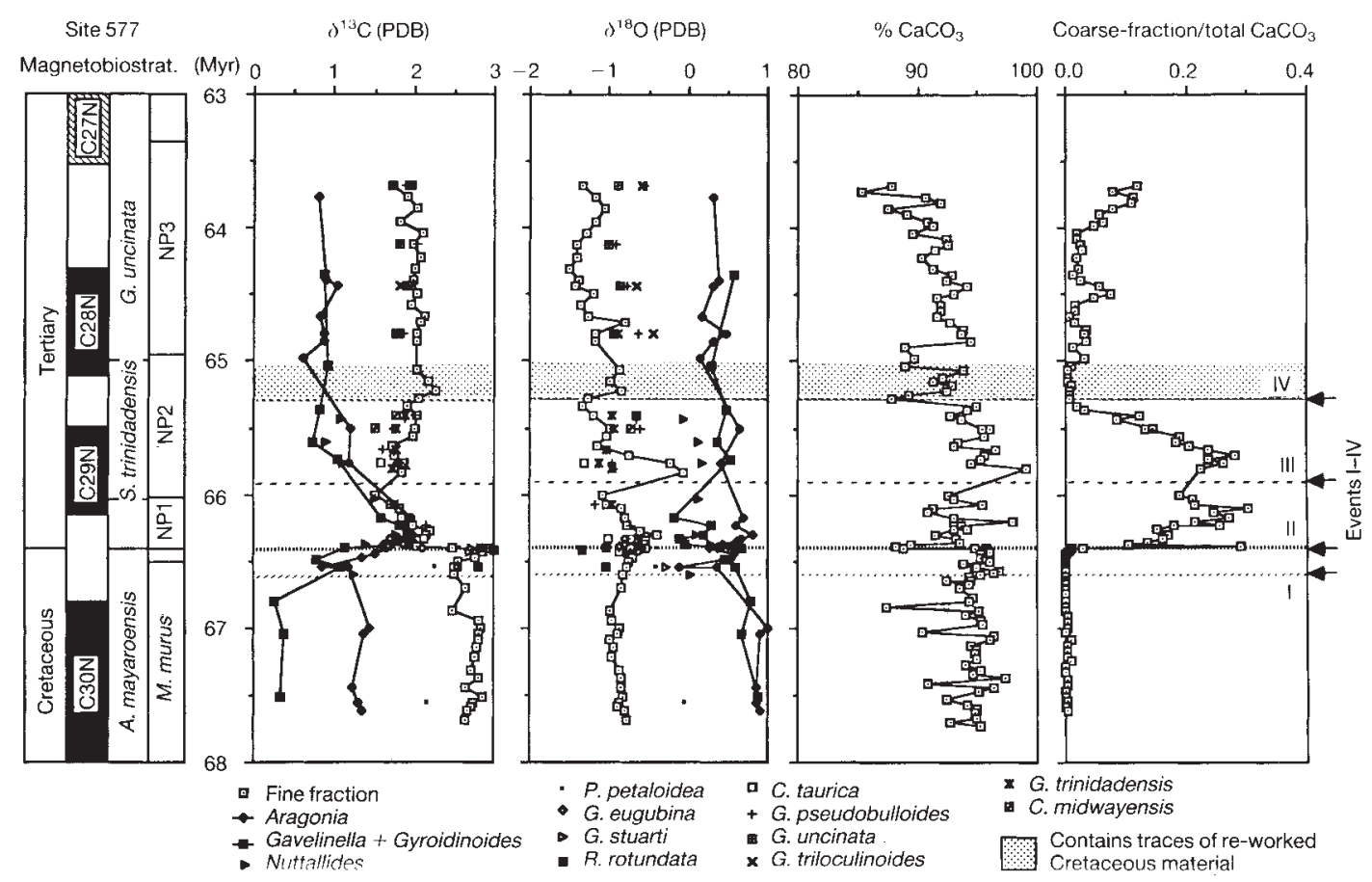

Fig. 1 Age plots of carbon and oxygen stable isotope compositions of fine-fraction carbonate (<63 $\mu$ m), benthic foraminifer Aragonia, trochospiral genera Gavelinella + Gyroidinoides, and Nuttallides, various species of planktonic foraminifera, and carbonate content of whole rock samples. All stable isotope data are expressed in the delta notation, $\delta$, in $\%$ relative to the PDB marine carbonate standard ${ }^{27}$. The final column shows the weight ratio $(\%)$ of coarse fraction $(>63 \mu \mathrm{m})$ to total carbonate. Age determinations were made using available magnetostratigraphy ${ }^{28}$ and nannofossil stratigraphy ${ }^{13}$ (presented on the far left) and the most recently published timescale ${ }^{29}$. Four separate events are recognized in the evolution of the stable isotope and carbonate content records and are denoted by the four dashed lines. The shaded area represents a portion of the sequence which contains re-worked Cretaceous fossils. The gap in sampling from 65.8 to 65.95 Myr encompasses the interval of an organic geochemistry core removed on board ship.

benthic foraminiferal genera (Fig. 1) is particularly interesting because of the observation that many species of modern benthic foraminifera do not reside directly on the sea floor but instead within the upper few centimetres of sediment, and therefore secrete their tests in carbon isotope equilibrium with the surrounding pore waters rather than with bottom waters ${ }^{10}$. In situ decay of organic matter in the upper few centimetres of sediment produces a pore-water $\delta^{13} \mathrm{C}$ gradient with a magnitude which is, in part, a function of the accumulation rate of organic carbon $\left(C_{\mathrm{org}}\right)^{11}$. Convergence of $\delta^{13} \mathrm{C}$ values of Aragonia and that of Gavelinella + Gyroidinoides across the K/T boundary may indicate that the pore-water $\delta^{13} \mathrm{C}$ gradient is eliminated as a result of the reduction in one $\mathrm{C}_{\text {org }}$ flux to sediments. The absence of benthic foraminiferal carbon isotope differences during the recovery period suggests that new $\mathrm{C}_{\text {org }}$ flux levels were lower than that of the latest Cretaceous.

Other evidence which suggest earliest Palaeocene reduced primary productivity involves carbonate and barium massaccumulation-rate data. In the absence of changes in the rate of dissolution, the rate of accumulation of biogenic carbonate should be proportional to production in surface water. Carbonate accumulation rates decline on average by a factor of four across the $K / T$ boundary in all pelagic marine sequences examined $^{3}$. In general, preservation of calcareous microfossils improves across the $\mathrm{K} / \mathrm{T}$ boundary at most localities ${ }^{4,12}$. Therefore, the decrease in carbonate accumulation rates from Maestrichtian to the early Palaeocene cannot be easily attributed to increased rates of dissolution and must have resulted from a decrease in the rate of $\mathrm{CaCO}_{3}$ production in surface waters.

The distribution of dissolved barium in the modern oceans is nutrient-like and appears to be mediated by biological activity $^{13,14}$. In the modern Pacific Ocean, Ba and organic-carbon sediment-trap fluxes are commonly proportional ${ }^{15}$. Because sediment pore waters are near saturation with respect to barite ${ }^{16}$, barite is typically preserved in sediments whereas $C_{\text {org }}$ is oxidized. Thus, Ba accumulation rates can be used as a proxy for $\mathrm{C}_{\text {org }}$ flux to the sediments ${ }^{17}$. At Site $577, \mathrm{Ba}$ accumulation rates decrease from $>0.2$ to $<0.1 \mathrm{mg} \mathrm{cm}^{-2}$ per $10^{3} \mathrm{yr}$ across the $\mathrm{K} / \mathrm{T}$ boundary (Fig. 3), reflecting the decreased rain rate of $\mathrm{C}_{\mathrm{org}}$.

We have recognized four discrete episodes in the evolution of the stable-isotope and carbonate records across the $\mathrm{K} / \mathrm{T}$ boundary and in the early Palaeocene at Site 577 . The first of these events begins at least $10^{5} \mathrm{yr}$ before the main plankton extinctions and the last occurs nearly $1.5 \times 10^{6} \mathrm{yr}$ later. We believe that these events represent significant changes in oceanic fertility, circulation and climate, which are accompanied by consequent effects on biotic evolution.

Event I (66.6 Myr), which precedes the $\mathrm{K} / \mathrm{T}$ boundary event, is marked by enrichment in both planktonic and benthic microfossil carbon isotope records, accompanied by a slight increase in carbonate content and an improvement in microfossil preservation. In addition, $\mathrm{Ba}$ accumulation rates decrease. The increase in $\delta^{13} \mathrm{C}$ of both the planktonic and benthic records probably indicates a change in $\delta^{13} \mathrm{C}$ of the oceanic TDC reservoir. This could have resulted from increased organic-carbon burial on continental margins (or decreased carbon fluxes from weathering) that are related to the latest Cretaceous transgression, which began at about $66.7 \mathrm{Myr}$ (ref. 18). In addition, there may have been changes in deep-water sources, increased oxygenation of deep waters and/or lower organic-carbon flux at Site 577 at this time. Enriched fine-fraction $\delta^{18} \mathrm{O}$ values also indicate cooling of surface waters; this suggests that the rate of oceanic turnover and ventilation of the deep reservoir increased before the $\mathrm{K} / \mathrm{T}$ boundary as the result of global cooling and intensification of thermohaline-driven circulation. The increase in relative proportions of the temperate planktonic foraminiferal 
Fig. 2 Expanded 2-Myr record across the K/ T boundary of the stable carbon and oxygen isotope data from Fig. 1. Shaded area represents a zone containing traces of re-worked Cretaceous microfossils.
Site 577

Age Magnetobiostrat.

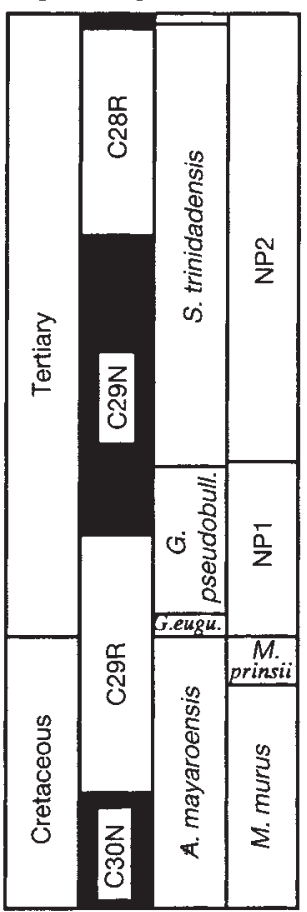

- Fine fraction

- Aragonia

- Gavelinella $\delta^{13} \mathrm{C}(\mathrm{PDB})$

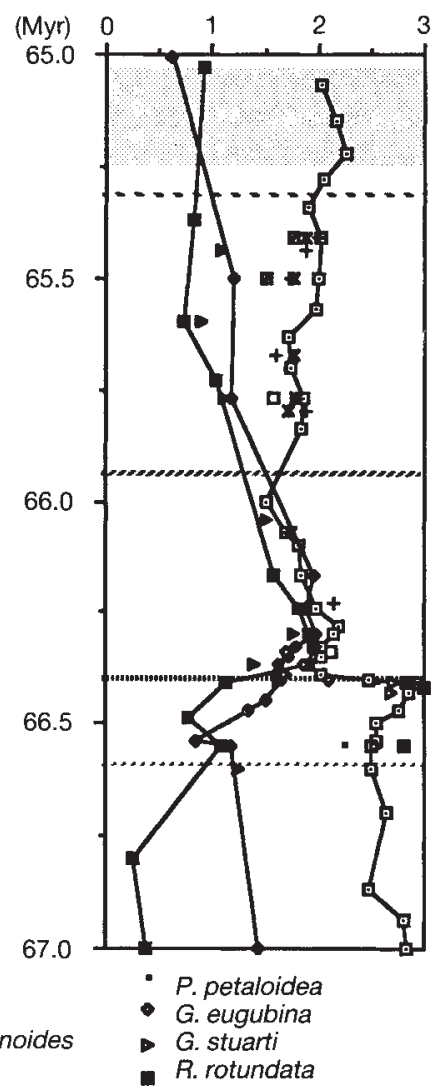

$\delta^{18} \mathrm{O}(\mathrm{PDB})$

$-$

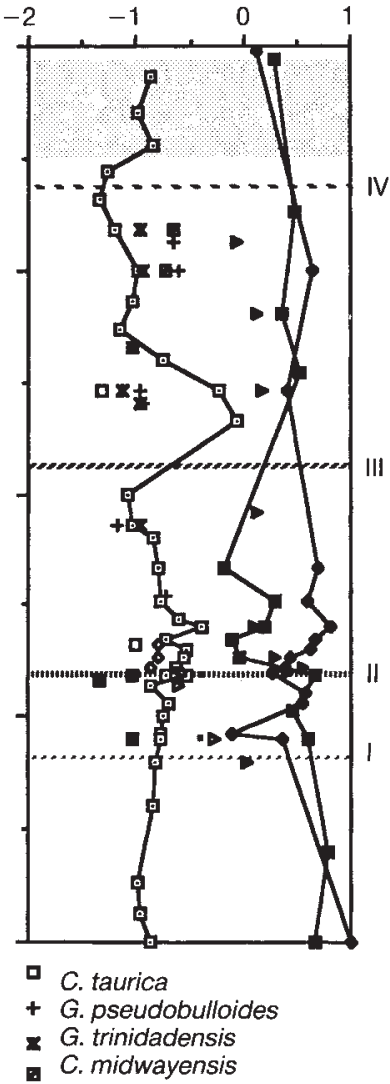

Fig. 3 Age plots of barium $(\mathrm{Ba})$, aluminium (Al) and carbonate mass accumulation rates (MAR), and $\mathrm{Ba} / \mathrm{Al}$ ratios, at Site 577. The accumulation rates were calculated using physical properties data from the DSDP Leg 86 volume and sedimentation rates based on the magneto- and nannofossil stratigraphy at left. Age assignments for the immediate post-boundary interval were averaged from the top of the Cretaceous (109.1 m.b.s.f., $66.4 \mathrm{Myr}$ ) to the base of Chron 29N (108.4 m.b.s.f., 66.17 Myr). As a result, we cannot resolve changes in accumulation rates that occurred on timescales of $10^{4} \mathrm{yr}$ or less at Site 577. Because the Base of Chron $30 \mathrm{~N}(\mathrm{C} 30 \mathrm{~N})$ or the $M$.
$\mathrm{CaCO}_{3} \mathrm{MAR}$

Site 577 (Myr) $\left(\mathrm{g} \mathrm{cm}^{-2} \mathrm{kyr}^{-1}\right)$

Magnetobiostrat.

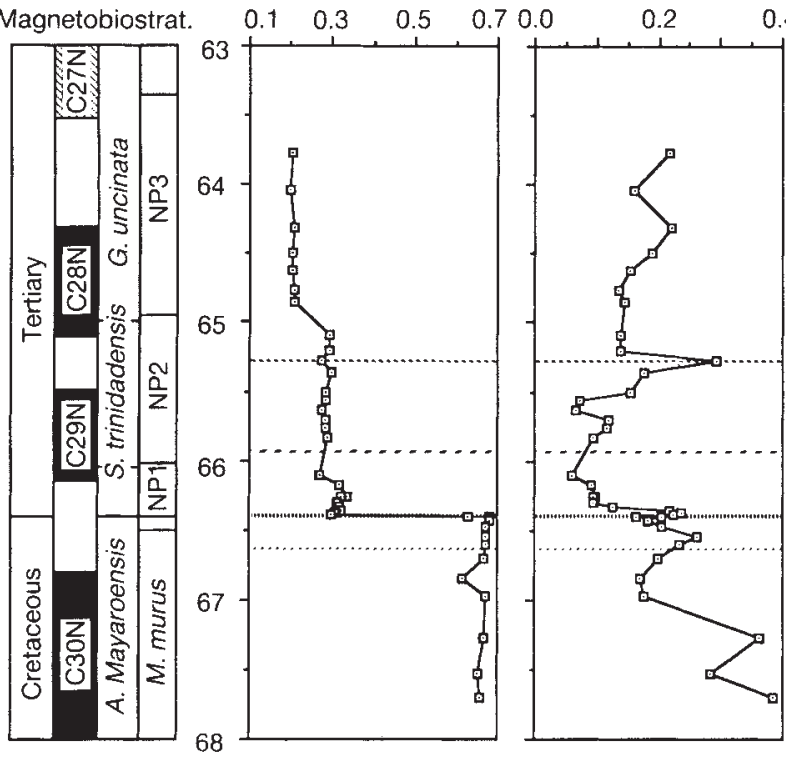

Ba MAR
$\left(\mathrm{mg} \mathrm{cm} \mathrm{cm}^{-2} \mathrm{kyr}^{-1}\right)$

Al MAR

$\left(\mathrm{g} \mathrm{cm}^{-2} \mathrm{kyr}^{1}\right)$

$\mathrm{Ba} / \mathrm{Al}$
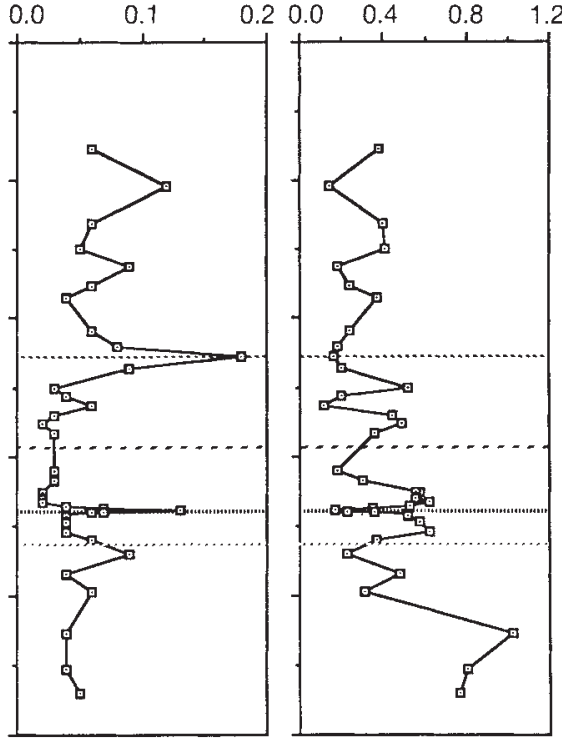

ratio represents weight ratio of $\mathrm{Ba}$ to $\mathrm{Al}_{2} \mathrm{O}_{3}$.

genus Heterohelicidae at this low latitude provides additional support for cooling before the $\mathrm{K} / \mathrm{T}$ boundary event ${ }^{4}$.

Event II: K/T boundary ( $66.4 \mathrm{Myr}$ ), the main plankton extinction and productivity crisis, features the rapid collapse of the surface-to-deep-water carbon isotope gradient and decreases in carbonate and $\mathrm{Ba}$ accumulation rates described above. A puzzling aspect of this event is the 100 -fold increase recorded in the concentration of foraminifera relative to total carbonate
(Fig. 1). There are three possible explanations for this phenomenon: (1) intensified deep circulation resulting in winnowing of the fine fraction; (2) less fragmentation and improved preservation of the more dissolution-susceptible planktonic foraminifera as a result of deepening of the carbonate compensation depth (CCD) and/or lowered rates of in situ dissolution brought about by decreased $\mathrm{C}_{\text {org }}$ decay within sediment pore waters; and (3) an ecological trophic-structure response to the 
extinctions and environmental change in which calcareous nannoplankton are replaced by siliceous or organic-walled phytoplankton. We favour preservation changes (2) as the possible origin of the increase in foraminifera concentrations. It is generally accepted that coccoliths tend to be more dissolutionresistant than foraminifera and that calcite dissolution above the calcite saturation horizon is driven mainly by titration by metabolic $\mathrm{CO}_{2}$ derived from $\mathrm{C}_{\text {org }}$ decay at or near the sedimentwater interface ${ }^{19}$. Dissolution at the shallow palaeodepth of the Shatsky Rise near site 577 would have been controlled to a large extent by metabolic $\mathrm{CO}_{2}$ production. Decay of $\mathrm{C}_{\text {org }}$ at the sediment-water interface would decline as a result of reduced $\mathrm{C}_{\text {org }}$ flux during the 'Strangelove' ocean event making bottom and pore water less corrosive to calcite. Furthermore, taking into account the large initial decrease in $\mathrm{CaCO}_{3}$ accumulation that occurred as a result of the productivity crisis, and assuming that riverine input of inorganic $\mathrm{C}$ and alkalinity remained constant, one would expect a rapid deepening of the CCD and much improved preservation of foraminifera across the $\mathrm{K} / \mathrm{T}$ boundary. Thus we explain the increased foraminiferal flux in the Palaeocene, implied by the higher relative proportion of foraminifers, by enhanced preservation.

Event III $(65.9 \mathrm{Myr})$ is characterized by the gradual return of the surface-to-deep-water carbon isotope gradient, a slight increase in $\mathrm{Ba}$ accumulation rates and a gradual decrease in the planktonic foraminifera concentrations. These changes indicate that surface-water productivity began to increase $\sim 0.5 \mathrm{Myr}$ after the $\mathrm{K} / \mathrm{T}$ boundary event, albeit at relatively low levels. Climate fluctuations of several degrees are indicated by variations in nannofossil and foraminiferal $\delta^{18} \mathrm{O}$. Rates of evolution of planktonic forams remained high ${ }^{20}$, suggesting continuing environmental instability.

Event IV (65.3 Myr) signals the full expression of the surfaceto-deep-water carbon isotope gradient and a decrease in planktonic foraminiferal concentrations to normal values. Aluminium accumulation rates also increased at this time. Because $\mathrm{Al}$ accumulation rates are probably a reflection of flux of aeolian detritus to this site ${ }^{21}$, the increased $\mathrm{Al}$ accumulation rates may represent climate change at this time and possibly an increase in wind strength. Environmental stability is indicated by a nearly constant $\delta^{13} \mathrm{C}$ gradient, relatively stable $\delta^{18} \mathrm{O}$ values and low rates of change of planktonic foraminiferal faunas in the $G$. uncinata zone $\mathrm{z}^{20}$.

The extinction of phyto- and zooplankton and disappearance of the carbon isotope gradient is abrupt and occurs over a period of less than $10^{4} \mathrm{yr}$. It is unlikely that a gradual environmental change occurring over a longer period of time (that is, $10^{5}-10^{6} \mathrm{yr}$ ) could have resulted in such a rapid and extreme collapse of the marine ecosystem unless some as yet unknown environmental threshold was exceeded ${ }^{22}$. The instantaneous environmental stress that would be brought about by a bolide impact provides a possible explanation for the collapse of primary productivity and its coincidence with an abundance of spherules and platinum-group metals at the $\mathrm{K} / \mathrm{T}$ boundary, as exhibited at Site 577 . It fails to explain, however, why primary productivity remained low for such a long period after the event.

It is possible that the $0.5-\mathrm{Myr}$ 'Strangelove' ocean may represent the normal recovery time for the biosphere following a sudden mass extinction event. An alternative explanation is that the slow recovery of primary productivity was the result of climate and oceanic circulation instability. The rate of speciation was extremely high for the first several $10^{6}$ years above the $\mathrm{K} / \mathrm{T}$ boundary at Site 577 , with one assemblage of planktonic foraminifera quickly replacing another ${ }^{20}$. Because the distributions of planktonic foraminifera are limited to particular water masses, the high turnover rate of assemblages suggests that surface-water conditions changed rapidly during the Danian. As a consequence, an efficient, highly structured ecosystem may have been incapable of developing. The origin of this climatic instability is uncertain but may prove to be related to feedback mechanisms involving the global carbon cycle $9,23-25$. Models predict that, following a rapid extinction event, atmospheric $p_{\mathrm{CO}_{2}}$ would have increased by as much as a factor of two or three on a timescale of several oceanic mixing cycles $^{26}$, as the result of nearly complete cessation of oceanic productivity. Such increases in $p_{\mathrm{CO}_{2}}$ would be expected to result in global warming. The nannofossil data, which represent the most complete time series, suggest a gradual $3{ }^{\circ} \mathrm{C}$ warming of surface waters during the initial $0.5 \mathrm{Myr}$ of the Palaeocene.

We thank D. McLean for comments on this manuscript, and M. Bender, K. Caldeira, B. Corliss, D. Fastovsky, A. Mackensen, D. McCorkle, K. Miller, C. Officer, M. Rampino and R. Thunell for discussions. Special thanks are extended to J. Gerstel for assistance during sample preparation. This research was supported by the NSF.

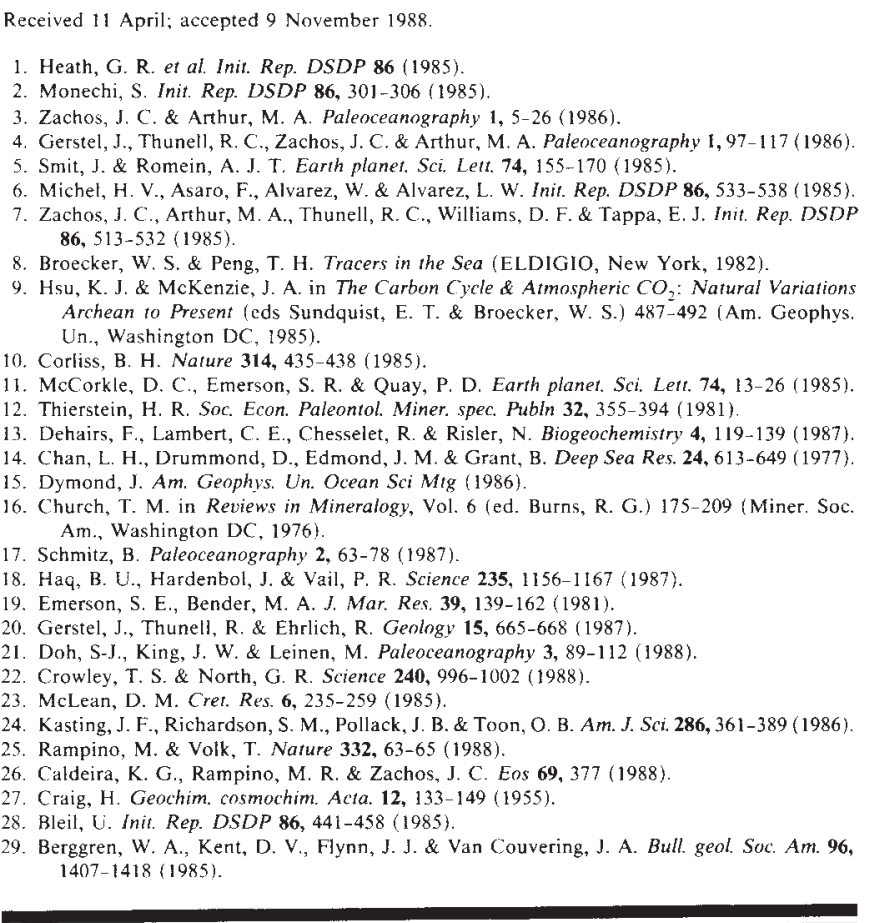

